DOI 10.22460/jpmi.v1i3.299-304

\title{
PENGHARGAAN DIRI DAN PENALARAN MATEMATIS SISWA MTs
}

\author{
Nasution Annisa Nur Sholihat ${ }^{1}$, Wahyu Hidayat ${ }^{2}$, Euis Eti Rohaeti ${ }^{3}$ \\ 1,2,3 IKIP Siliwangi, Jl. Terusan Jenderal Sudirman, Cimahi, Jawa Barat, Indonesia \\ ${ }^{1}$ nasutionannisa17@gmail.com, ${ }^{2}$ wahyu@ikipsiliwangi.ac.id, ${ }^{3}$ e2rht@ikipsiliwangi.ac.id
}

Diterima: 20 April 2018; Disetujui: 28 Mei 2018

\begin{abstract}
This study aims to analyze and examine in depth about the ability of mathematical reasoning that is influenced by self-esteem of MTs students. The method in this research using correlational method with quantitative approach. The population in this study were students of MTs in Kota Cimahi and the samples were 20 people determined by purposive sampling technique in one of MTs in Cimahi City. Instrument in this research is test of critical thinking ability of mathematic as much as 5 item and scale of student self confidence as 30 scale statement. The results of this study concluded that the mathematical reasoning ability of students of MTs is positively influenced by their self-esteem of $52.5 \%$, while $47.5 \%$ is influenced by factors other than self-esteem students.
\end{abstract}

Keywords: Self-Esteem, Penalaran Matematis

\begin{abstract}
Abstrak
Penelitian ini bertujuan untuk menganalisis dan menelaah secara mendalam tentang kemampuan penalaran matematis yang dipengaruhi penghargaan diri siswa MTs. Metode dalam penelitian ini menggunakan metode korelasional dengan pendekatan kuantitatif. Populasi dalam penelitian ini adalah siswa MTs di Kota Cimahi dan sampelnya sebanyak 20 orang yang ditetapkan dengan teknik purposif sampling pada salah satu MTs di Kota Cimahi. Instrumen dalam penelitian ini berupa tes kemampuan berpikir kritis matematis sebanyak 5 butir soal dan skala kepercayaan diri siswa sebanyak 30 skala pernyataan. Hasil penelitian ini memperoleh kesimpulan bahwa, kemampuan penalaran matematis siswa MTs dipengaruhi positif oleh penghargaan dirinya sebesar 52,5\%, sedangkan 47,5\% dipengaruhi oleh faktor selain penghargaan diri siswa.
\end{abstract}

Kata Kunci: Penghargaan Diri, Penalaran Matematis

How to cite: Sholihat, N. A. N., Hidayat, W., \& Rohaeti, E. E. (2018). Penghargaan Diri dan Penalaran Matematis Siswa MTs. JPMI - Jurnal Pembelajaran Matematika Inovatif, 1 (3), 299-304.

\section{PENDAHULUAN}

Tujuan pembelajaran matematika yakni: (1) melatih bagaimana memahami sesuatu melalui berpikir dan bernalar untuk menarik suatu kesimpulan, (2) mengembangkan kreativitas peserta didik dengan melibatkan intuisi, imajinasi, dan suatu penemuan yang dikembangkan dari pemikiran rasa ingin tahu, divergen, orisinil, sehingga dapat membuat prediksi atau dugaan untuk memecahkan suatu permasalahan yang dihadapi, (3) mengembangkan kemampuan memecahkan masalah, dan (4) mengembangkan kemampuan menyampaikan informasi dan mengkomunikasikan gagasan (Dilla, Hidayat, \& Rohaeti, 2018; Hermawan, \& Hidayat, 2018; Hidayat, 2011; 2012; 2017; Hidayat, \& Prabawanto, 2018; Rahmi, Nadia, Hasibah, \& Hidayat, 2017; Sholihat, Hidayat, \& Rohaeti, 2018). 
Pembelajaran matematis diarahkan untuk memberi peluang berkembangnya kemampuan bernalar, kesadaran terhadap kebermanfaatan matematika, menumbuhkan rasa percaya diri, sikap objektif dan terbuka untuk menghadapai masa depan yang selalu berubah.(Mulyana \& Sumarmo, 2015). Pernyataan tersebut menunjukan bahwa penalaran dibutuhkan untuk membangun suatu gagasan matematika dan untuk menunjukan bukti kebenaran dari gagasan tersebut.

Kemampuan penalaran matematis adalah kemampuan berpikir dan menggunakan aturan, sifat-sifat, dan logika berdasarkan konsep atau pemahaman yang telah didapat sebelumnya, kemudian konsep atau pemahaman tersebut saling berhubungan satu sama lain dan diterapkan dalam permasalahan baru sehingga didapat keputusan baru yang logis dan dapat dipertanggungjawabkan atau dibuktikan kebenarannya.

Salah satu komponen afektif yang perlu diperhatikan dalam pembelajaan matematis adalah rasa penghargaan diri (Self Esteem). Pada dasarnya tiap individu memiliki keinginan dihargai (Tresnawati, Hidayat, \& Rohaeti, 2017). Rasa penghagaan diri adalah keseluruhan penilaian positif dan negatif seseorang dalam menghargai diri sendiri baik menghargai kelebihan maupun kekurangan yang dimiikinya (Hendriana, Rohaeti, \& Sumarmo, 2017).

\section{METODE}

Metode dalam penelitian ini menggunakan metode korelasional dengan pendekatan kuantitatif yang bertujuan untuk mengetahui dengan menganalisis dan menelaah secara mendalam tentang kemampuan penlaran matematis yang dipengaruhi pengargaan diri siswa MTs. Populasi dalam penelitian ini adalah siswa MTs di Kota Cimahi. Sedangkan sampelnya sebanyak 20 orang yang ditetapkan secara purposif pada salah satu MTs di Kota Cimahi. Instrument dalam penelitian ini menggunakan tes dan non tes. Instrument tes tersebut didasarkan pada penilaian karakteristik yang baik terhadap kemampuan penalaran matematis, sedangkan instrument non tes didasarkan pada penilaian karakteristik yang baik terhadap penghargaan diri siswa. Tes kemampuan berpikir kritis matematis sebanyak 5 butir soal dan skala penghargaan diri siswa sebanyak 30 skala pernyataan. Data hasil penelitian diolah dan dianalisis menggunakan uji statistika regresi. Namun sebelum dilakukan uji statistika regresi, dilakukan terlebih dahulu pengujian normalitas data dan uji linearitas.

Adapun contoh instrumen tes dan non-tes secara berurutan disajikan pada gambar 1 dan 2 berikut ini.

1. Ada beberapa kubus-kubus kecil yang mempunyai panjang rusuk $4 \mathrm{~cm}$.

a. Jika terdapat 8 buah kubus kecil, 15 buah kubus kecil, 27 buah kubus kecil, manakah kumpulan kubus-kubus kecil tersebut yang dapat disusun sehingga membetuk kubus baru yang lebih besar?

b. Buatlah sebuah kesimpulan berdasarkan jawaban pada poin a.

2. Sebuah perusahaan memproduksi cokelat dengan ukuran panjang $6 \mathrm{~cm}$, lebar $4 \mathrm{~cm}$, dan tinggi $2 \mathrm{~cm}$. cokelat-coklat tersebut akan dikemas kedalam dus yang berukuran panjang $24 \mathrm{~cm}$, lebar $12 \mathrm{~cm}$, dan tinggi $6 \mathrm{~cm}$. seorang pegawai akan menyusun cokelat dengan posisi yang sama dalam dus tersebut.

a. Ada berapa banyak posisi cokelat yang bisa disusun oleh pegawai tesebut ?

b. Apakah ada perbedaan jumlah cokelat dalam dus kemasan dengan berbagai posisi susunan cokelat tersebut ? jelaskan alasannya.

Gambar 1. Instrumen tes tentang kemampuan penalaran matematis siswa 


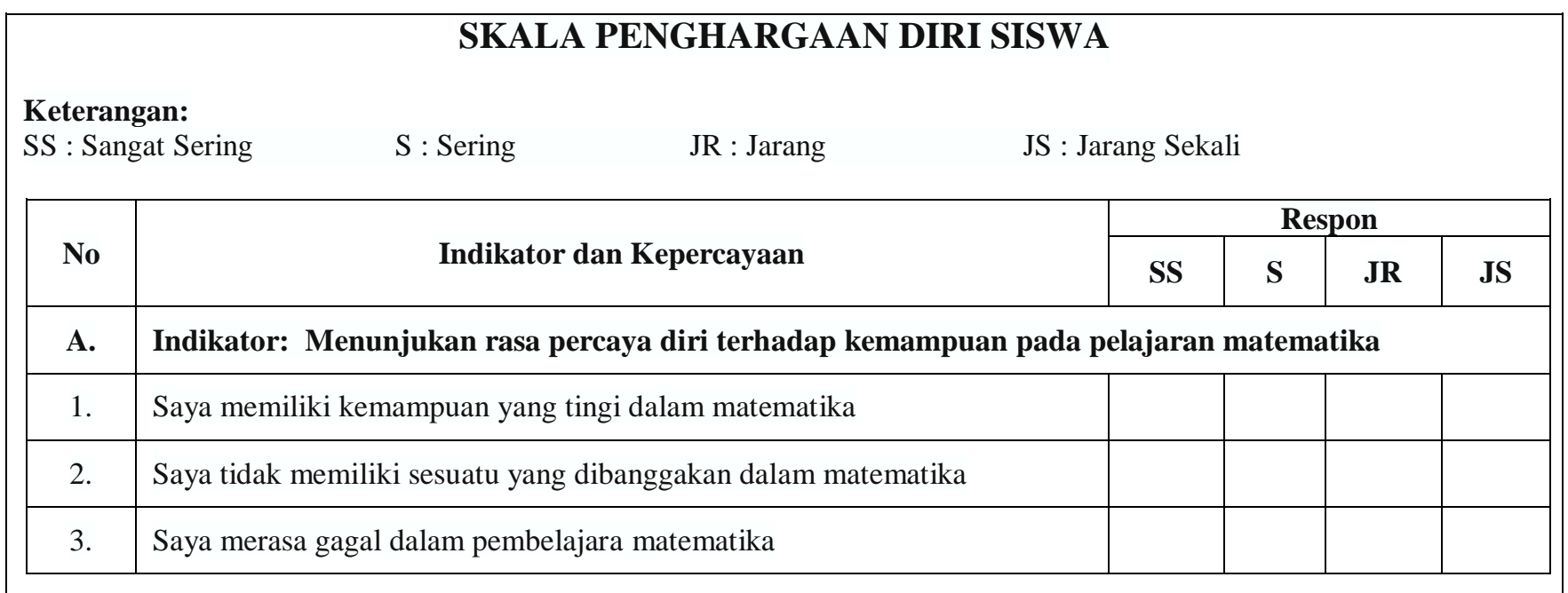

Gambar 2. Instrumen non tes tentang penghargaan diri siswa

\section{HASIL DAN PEMBAHASAN}

\section{Hasil}

Berdasarkan hasil analisis data diatas, diperoleh bahwa kedua variabel yaitu kemampuan penalaran matematis dan penghargaan diri siswa berdistribusi normal. Selanjutnya dilakukan uji linearitas kemampuan penalaran matematis atas penghargaan diri siswa dengan hasil pengujian disajikan pada Tabel 1 berikut.

Tabel 1. Uji Linearitas antara Penghargaan Diri dan Kemampuan Penalaran Matematis Siswa

\begin{tabular}{|c|c|c|c|c|c|c|c|}
\hline & & & $\begin{array}{l}\text { Sum of } \\
\text { Squares }\end{array}$ & $d f$ & $\begin{array}{l}\text { Mean } \\
\text { Square }\end{array}$ & $F$ & Sig. \\
\hline \multirow{5}{*}{$\begin{array}{l}\text { Kemampuan } \\
\text { Penalaran * Self } \\
\text { Esteem }\end{array}$} & \multirow{3}{*}{$\begin{array}{l}\text { Between } \\
\text { Groups }\end{array}$} & (Combined) & 78.300 & 13 & 6.023 & 1.364 & 0.368 \\
\hline & & Linearity & 28.896 & 1 & 28.896 & 6.543 & 0.043 \\
\hline & & $\begin{array}{l}\text { Deviation from } \\
\text { Linearity }\end{array}$ & 49.404 & 12 & 4.117 & 0.932 & 0.570 \\
\hline & \multicolumn{2}{|c|}{ Within Groups } & 26.500 & 6 & 4.417 & & \\
\hline & \multicolumn{2}{|l|}{ Total } & 104.800 & 19 & & & \\
\hline
\end{tabular}

Berdasarkan hasil uji linearitas antara penghargaan diri dan kemampuan penalaran matematis siswa terlihat, bahwa terdapat hubungan yang linear.

Selanjutnya dilakukan uji statistika regresi untuk melihat apakah terdapat pengaruh dari penghargaan diri dan kemampuan penalaran matematis dengan hasil pengujian disajikan pada Tabel 2 dan Tabel 3 berikut. 
Tabel 2. Uji Regresi antara Penghargaan Diri dan Kemampuan Penalaran Matematis Siswa

\begin{tabular}{llccccc}
\hline Model & $\begin{array}{c}\text { Sum of } \\
\text { Squares }\end{array}$ & df & Mean Square & F & Sig. \\
\hline 1 & Regression & 28.896 & 1 & 28.896 & 6.852 & $0.017^{\text {a }}$ \\
& Residual & 75.904 & 18 & 4.217 & & \\
& Total & 104.800 & 19 & & & \\
\hline
\end{tabular}

Tabel 3. Model Summary

\begin{tabular}{ccccc}
\hline Model & R & R Square & $\begin{array}{c}\text { Adjusted R } \\
\text { Square }\end{array}$ & $\begin{array}{c}\text { Std. Error of the } \\
\text { Estimate }\end{array}$ \\
\hline 1 & $0.525^{\mathrm{a}}$ & 0.276 & 0.235 & 2.054 \\
\hline
\end{tabular}

Dari Tabel diatas, kita dapat mengetahui hubungan antara Self Esteem dan Kemampuan Penalaran cukup signifikan. Berdasarkan pengujian regresi pada Tabel 2, didapat nilai Sig. sebesar 0,017 yang mengakibatkan bahwa penghargaan diri siswa secara signifikan memberikan pengaruh yang positif terhadap kemampuan penalaran matematis siswa pada taraf signifikansi yaitu 5\%. Selain itu besarnya koefisien korelasi adalah 0,525 dan nilai koefisien determinasi sebesar 0,276. Hal ini dapat diartikan bahwa kemampuan penalaran matematis siswa dipengaruhi oleh penghargaan diri siswa sebesar $52.5 \%$ sedangkan $47,5 \%$ dipengaruhi oleh faktor lain di luar penghargaan diri siswa.

Adapun persamaan regresi dari hasil pengujian tentang pengaruh penghargaan diri terhadap kemampuan penalaran matematis siswa adalah sebagai berikut:

$Y=-4,172+0,160 x$

Hal ini dapat diinterpretasikan bahwa apabila penghargaan diri siswa bernilai 0 (nol), maka kemampuan penalaran matematis siswa bernilai - 4,172. Selain itu terlihat pula bahwa koefisien dari penghargaan diri siswa bernilai positif artinya terdapat pengaruh yang positif antara penghargaan diri terhadap kemampuan penalaran matematis siswa. Sehingga dapat disimpulkan bahwa semakin tinggi penghargaan diri yang dimiliki siswa, maka akan semakin tinggi pula kemampuan penalaran matematis siswa tersebut.

\section{Pembahasan}

Dari hasil analisis data, hasil penelitian terlihat bahwa terdapat pengaruh yang positif antara penghargaan diri terhadap kemampuan penalaran matematis siswa, dan penyebab terjadinya pengaruh positif tersebut diantaranya: siswa yang memiliki sikap penghargaan diri dalam matematika cenderung lebih berani dan percaya diri dalam mengambil langkah penyelesaian soal, di luar prosedur pada umumnya. Siswa yang memiliki penghargaan diri dalam matematika cenderung memiliki ide atau jawaban yang banyak dalam penyelesaian soal atau memiliki lebih dari satu cara dalam menyelesaikan soal.

Selain itu, untuk siswa dengan sikap penghargaan diri yang kurang dalam matematika akan cenderung mengerjakan penyelesaian soal sesuai dengan prosedur dan lebih mengandalkan hapalan dan menalar, sehingga siswa tersebut menjadi lemah dalam pengambilan keputusan saat proses penyelesaian masalah yang dialaminya. 
Hasil pekerjaan siswa dengan sikap penghargaan diri dalam matematika disajikan pada Gambar 3 dan Gambar 4 berikut.

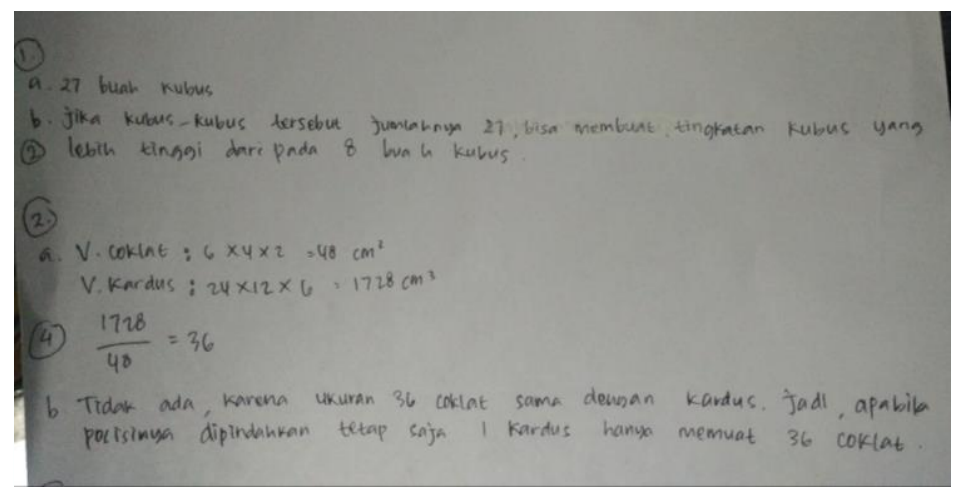

Gambar 3. Hasil pekerjaan siswa dengan sikap penghargaan diri yang baik

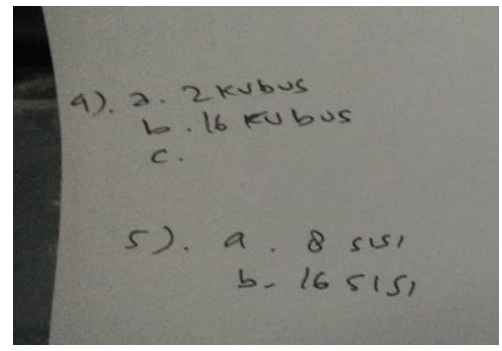

Gambar 4. Hasil pekerjaan siswa dengan sikap penghargaan diri yang kurang baik

Pada (Gambar 3) terlihat hasil jawaban siswa yang menyelesaikan permasalahan secara terstruktur dan mendetail. Jadi setelah mendetail, karna siswa mencari penyelesaian dari permasalahan tersebut. Hal ini sejalan dengan penelitian Kusdinar, Sukestiyarno, Isnarto, \& Istiandaru (Istiandaru, 2017) yang berpendapat bahwa dalam proses membuktikan suatu permasalahan, diperlukan kemampuan siswa mulai dari merumuskan ide awal dan menyusun strategi penyelesaian.

Berbeda dengan jawaban siswa yang memiliki skala sikap penghargaan diri dengan kategori kurang baik (Gambar 4) terlihat bahwa siswa tersebut memaksakan jawaban tanpa memikirkan ide awal penyelesaiannya terlebih dahulu. Sehingga ia merasa kesulitan dan pada akhirnya siswa tersebut menyerah begitu saja dengan jawaban yang tidak terselesaikan dari permasalahan yang diberikan

\section{KESIMPULAN}

Berdasarkan hasil analisis dan pembahasan, kesimpulan yang diperoleh adalah self esteem siswa tentang matematika dalam pembelajaran secara umum mempengaruhi kemampuan penalaran siswa. 


\section{DAFTAR PUSTAKA}

Dilla, S. C., Hidayat, W., \& Rohaeti, E. E. (2018). Faktor Gender dan Resiliensi dalam Pencapaian Kemampuan Berpikir Kreatif Matematis Siswa SMA. Journal of Medives, 2(1), 129-136.

Hendriana, H., Rohaeti, E. E., \& Sumarmo, U. (2017). Hard Skill \& Soft Skill Matematik Siswa (Edisi Kesa). BANDUNG: PT Refika Bandung.

Hermawan, A. S., \& Hidayat, W. (2018). Meningkatkan Kemampuan Penalaran Matematik Siswa SMP Melalui Pendekatan Penemuan Terbimbing. JPMI (Jurnal Pembelajaran Matematika Inovatif), 1(1), 7-20.

Hidayat, W. (2011). Meningkatkan Kemampuan Berpikir Kritis dan Kreatif Matematik Siswa Melalui Pembelajaran Kooperatif Think-Talk-Write (TTW) (Doctoral dissertation, Universitas Pendidikan Indonesia).

Hidayat, W. (2012). Meningkatkan Kemampuan Berpikir Kritis dan Kreatif Matematik Siswa SMA Melalui Pembelajaran Kooperatif Think-Talk-Write (TTW). In Seminar Nasional Penelitian, Pendidikan dan Penerapan MIPA.

Hidayat, W. (2017). Adversity Quotient dan Penalaran Kreatif Matematis Siswa SMA dalam Pembelajaran Argument Driven Inquiry pada Materi Turunan Fungsi. KALAMATIKA Jurnal Pendidikan Matematika, 2(1), 15-28.

Hidayat, W., \& Prabawanto, S. (2018, January). Improving students' creative mathematical reasoning ability students through adversity quotient and argument driven inquiry learning. In Journal of Physics: Conference Series (Vol. 948, No. 1, p. 012005). IOP Publishing.

Istiandaru, A. (2017). Krulik and Rudnik Model Heuristic Strategy in Mathematics Problem Solving. International Journal on Emerging Mathematics Education, 1(2), 205-210. https://doi.org/http://dx.doi.org/10.12928/ijeme.v1i2.5708

Mulyana, A., \& Sumarmo, U. (2015). Meningkatkan Kemampuan Penalaran Matematik Dan Kemandirian Belajar Siswa Smp Melalui Pembelajaran Berbasis Masalah. Jurnal Ilmiah STKIP Siliwangi Bandung, Vol 9 No.1(1), 40-51.

Rahmi, S., Nadia, R., Hasibah, B., \& Hidayat, W. (2017). The Relation between Self-Efficacy toward Math with the Math Communication Competence. Infinity Journal, 6(2), 177182.

Sholihat, N. A. N., Hidayat, W., \& Rohaeti, E. E. (2018). FAKTOR KEMAMPUAN PENALARAN MATEMATIS DAN PENGHARGAAN DIRI SISWA SMP. JPMI (Jurnal Pembelajaran Matematika Inovatif), 1(1), 1-6.

Tresnawati, T., Hidayat, W., \& Rohaeti, E. E. (2017). Kemampuan Berpikir Kritis Matematis dan Kepercayaan Diri Siswa SMA. Symmetry: Pasundan Journal of Research in Mathematics Learning and Education, 2(2), 39-45. 